DOI https://doi.org/10.18551/rjoas.2017-07.21

\title{
INDONESIA'S RICE POTENSIALS ON TRADE LIBERALIZATION OF THE ASEAN ECONOMIC COMMUNITY
}

\author{
Wisnujati Nugrahini Susantinah, Hanani Nuhfil, Setiawan Budi, Syafrial \\ University of Brawijaya \& Wijaya Kusuma University, Indonesia \\ *E-mail: nugrahiniwisnujati@yahoo.co.id
}

\begin{abstract}
Food Agriculture Organization predicts that food shortages in developing countries by 2030 will reach 8 billion. According to Dimithe, strategies to reduce production costs lie in increasing crop yields, improvement of marketing strategies, and the betterment of rice quality (1997). This study aims to determine the trend of rice production costs of Indonesia and ASEAN countries; to know the factors that affect the area of rice harvest, identifying the factors that affect rice production, as well as, the factors that affect rice import in Indonesia.
\end{abstract}

\section{KEY WORDS}

ASEAN economic community, import, production cost.

Food Agriculture Organization (FAO) predicts that food shortages in developing countries by 2030 will reach 8 billion and to sustain the population of the world it will require 270 tons of rice. Developing countries, identical to countries that are still ineffective in their usage of farming technologies will depend on import as their source of food (Krisnamurthi, 2006). Learning from Thailand's declining export competitiveness to Vietnam (Asia News Monitor, 2010) according to the research, such problem may be resolved by lowering production costs, increasing the yield of crops, improving marketing strategies, and the betterment of rice quality. According to Dimithe, effective use of fertilizer, efficient utilization of labor, reducing the time span of plant growth, facilitating farmers to adopt new innovations are ways to lower the cost of production. From the examples above, it can be inferred that a high production cost will cause a country's export capacity to be less than what it originally can be. In order to achieve the result of the analysis, several steps are taken namely; analyzing the trend of production costs, as well as, factors that affect the cost of production and import Indonesia

This paper will consult the research conducted by Junaedi, Mohammad; Daryanto; Heny Kuswanti Suwarsinah; Sinaga, Bonar Marulitua; Hartoyo, Sri. Furthermore, it will look into the International Journal of Food and Agricultural Economics; Fethiye 4.2 (Apr 2016) where it indicates that the study uses data from 4,203 paddy fields farmers in four different regions in Indonesia. This paper will also examine the Cost Structure of Food Crops Survey 2011 conducted by BPS. Metal frontier analysis proves that efficiency levels in four areas cannot be compared to one another. In general, all coefficients of the variable production functions are positive and significant, as expected, the area of harvest is the strongest factor that affects rice production.

In a study conducted by A. Muhammad-Lawal, J. Mengudu, A.F. Ayanlere, A.B. Mohammed, M.E. Olajogun, 2013, shows that Nigeria the world's largest rice-importing country spends up to the US $\$ 756$ million annually on rice. The reason as to that phenomenon is that, Nigerian production cannot compensate to the country's domestic demand.

\section{METHODS OF RESEARCH}

This paper uses the specification of rice econometric model in Indonesia, which is arranged into six equations: consisting of three structural equations and three identity equations. The structural equation is a representation of the endogenous variables of 
exogenous variables that operatively rely on the mark and the value of the estimation Method of Parameter Estimation and Testing Model.

The data used are that of data from 1991 until 2013.

The Rice Production equation is the identity equation as follows:

1. Indonesian Rice Production:

$$
Q B=A P B * R B
$$

2. Area of Indonesian Rice Harvest in Year t (APBt):

$$
A P B t=a 0+a 1 P B t+a 2 P J A G t+a 3 P P U K t+a 4 K E D t+a 5 P K T L A t+a 6 A P B t-1+\mu 1
$$

3. Rice productivity of rice to $t(R B t)$ :

$$
\mathrm{RBt}=\mathrm{b} 0+\mathrm{b} 1 \mathrm{~PB}+\mathrm{b} 2 \mathrm{PPUKt}+\mathrm{b} 3 \mathrm{Tt}+\mathrm{b} 4 \mathrm{Wt}+\mathrm{b} 5 \mathrm{PPESt}+\mathrm{b} 6 \mathrm{RB}-1+\mu 2
$$

Rice import on ASEAN Markets. Indonesia has been importing from countries around ASEAN those countries are Thailand and Vietnam. The total import of Indonesian rice from Vietnam and Thailand is:

$$
M B=M I T H t+M I V I T t
$$

The Influential Factors in the Import of Indonesian Rice are:

$$
\mathrm{MBt}=\mathrm{c} 0+\mathrm{c} 1 \mathrm{PM}+\mathrm{c} 2 \mathrm{DTt}+\mathrm{c} 3 \mathrm{QBt}+\mathrm{c} 4 \mathrm{ERIt}+\mathrm{c} 5 \mathrm{MBt}-1+\mu 3
$$

The price of import of Rice Indonesia (PM), Variable price Import Indonesia rice is the sum of the world rice price (in US dollars (PW) with trade restrictions set Indonesia (in US dollars), mathematically are:

$$
P M=P W+R E S T t ~ * P W \text { or } P M t=(1-R E S T t) P W
$$

Where: $\mathrm{PB}=$ Price of Rice $(\mathrm{Rp} / \mathrm{Ton}) ; \mathrm{T}=$ interest rate / credit interestrate (percent); $W=$ Labor Wage (Rp / HOK); PKED = Soybean Price $(\mathrm{Rp} / \mathrm{Ton})$; PPUK = fertilizer price $(\mathrm{Rp} /$ ton); PJAG = Corn Price $(\mathrm{Rp} / \mathrm{Ton}) ; \mathrm{PPES}=$ Pesticide Price $(\mathrm{Rp} /$ Liter); $\mathrm{QB}=$ Indonesia Rice Production; $\mathrm{ERI}=$ Rupiah Exchange Rate against US Dollar;

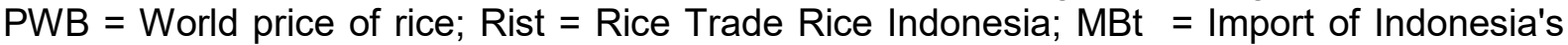
totalrice in Year $\mathrm{t}$; MITHt $=$ Import Indonesian rice fromThailand in year $t$; MIVIT $t=$ import rice from Vietnam in year $t$.

\section{RESULT OF STUDY}

This paper's aim is to develop trend line through examination of data received from FAO through the year of 1990 to 2014. In addition, this paper will examine the trend line of rice production cost from Indonesia, other countries in ASEAN (e.g., Vietnam, Thailand) in order to provide comparison between data for better understanding of the result.

The cost of production will, later on, for the cost of principal production; thus, the tendency of production costs will show the prediction of a country's principal rice cost.

Vietnam's rice production costs tend to rise sharply, in 2014 the production cost ranges from 300 US dollars up to 1300 US dollars. In terms of production cost, it never decreases; remaining constant up to the range of 10 US dollars in 1981, 1994, and 2004.

The performativity of Indonesian rice can be identified from several variables namely the production, productivity, the area of rice harvested in Indonesia. The results of the analysis of rice harvested in Indonesia are shown in the following results (Table 1). 


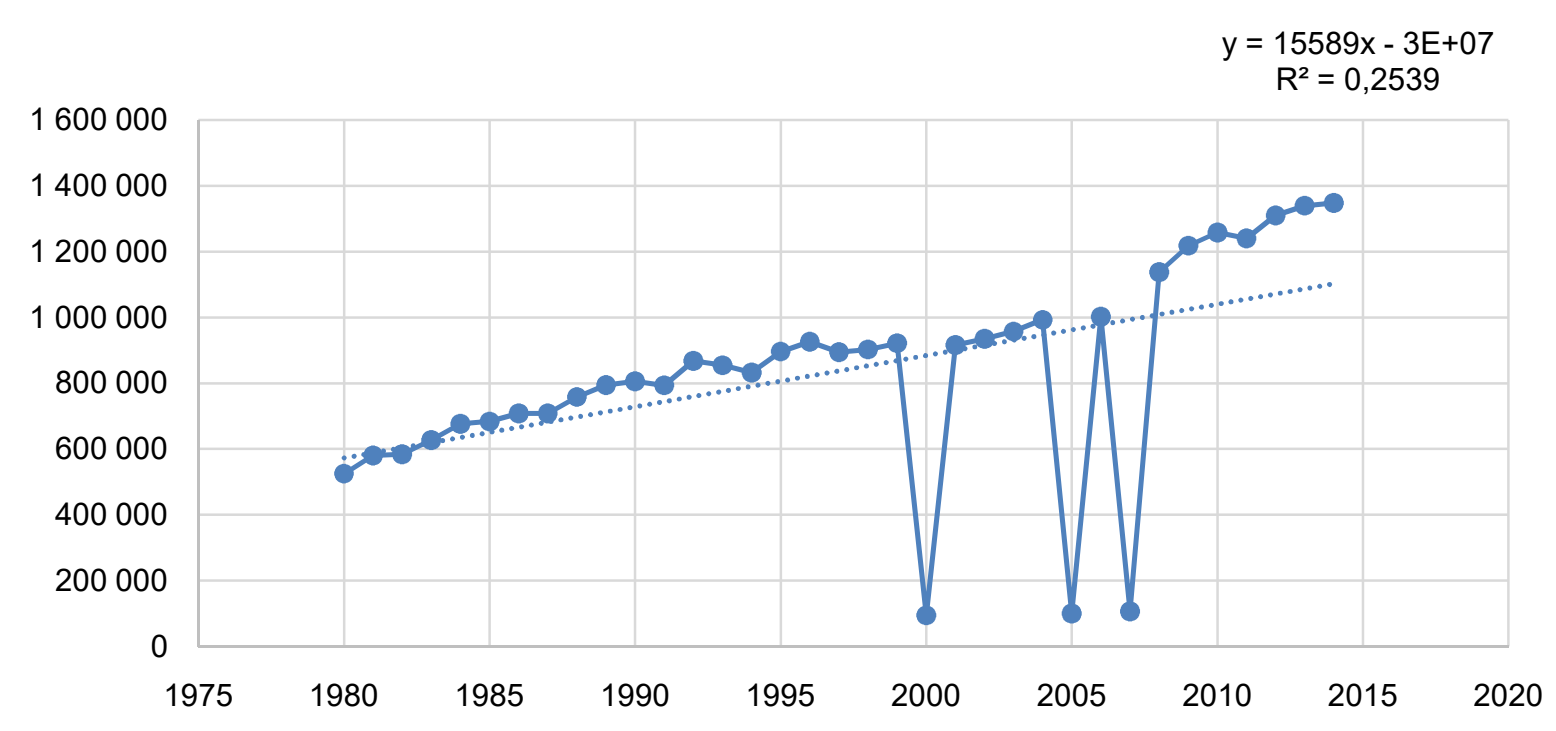

Figure 1 - Indonesia's Cost of Production

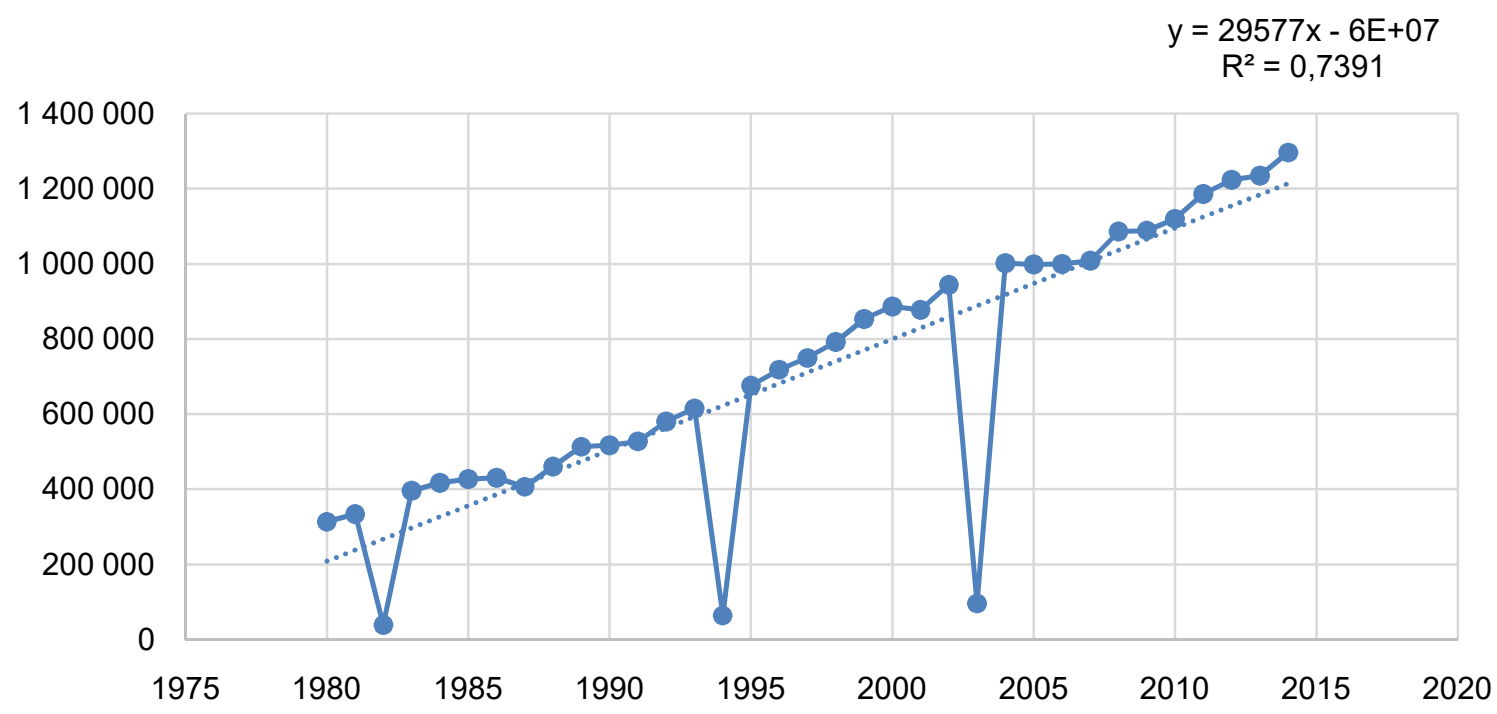

Figure 2 - Vietnam's Cost of Production

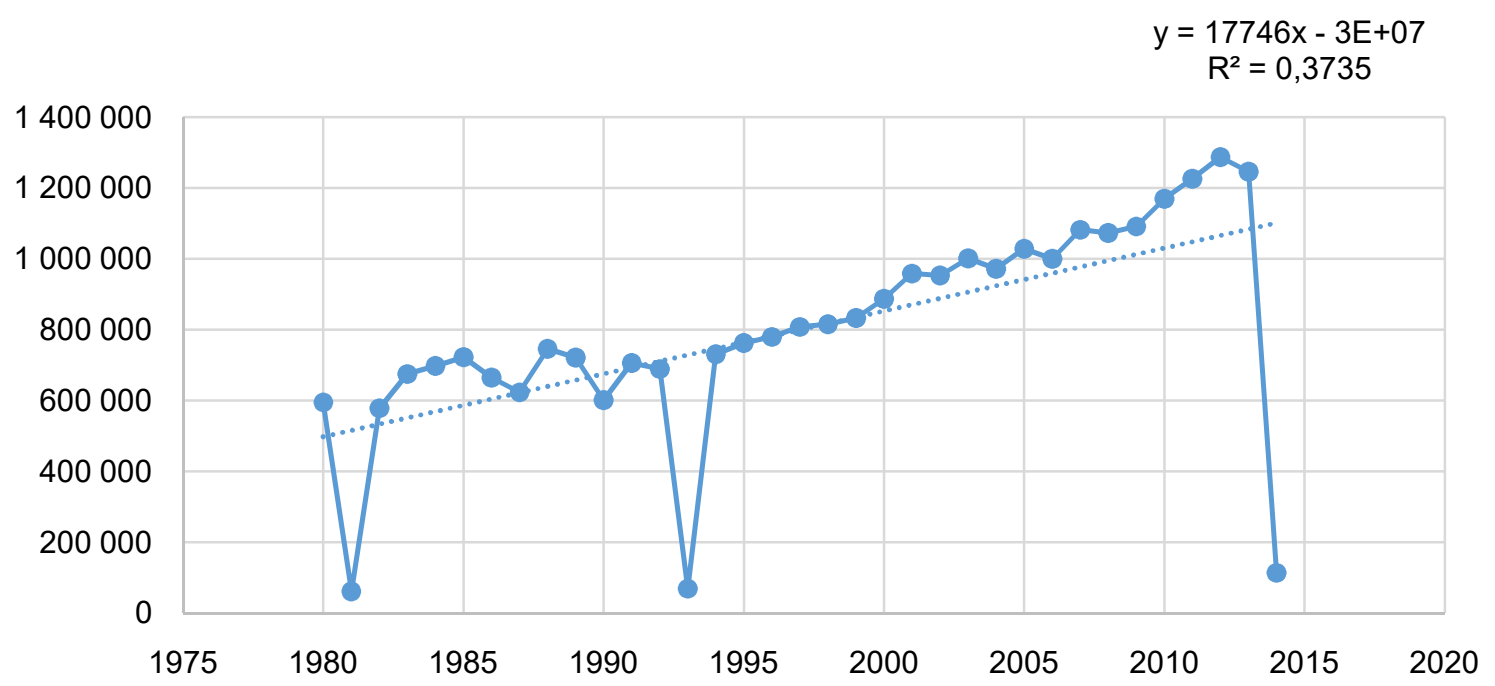

Figure 3 - Thailand's Cost of Production 
Influential Variables in Relation to the Crop Rice Area (APB) in Indonesia:

Table 1 - Results Two-Stage Least Square against Rice Harvest Area in Indonesia

\begin{tabular}{llll}
\hline Variable & Coefficient & t-value & Significant \\
\hline Constanta & 8490473 & 18.62 & 0.000 \\
PB & -84.461 & 0.12 & 0.906 \\
PJAG & 0.840 & 0.78 & 0.443 \\
PPUK & -5.620 & 0.33 & 0.746 \\
PKED & 0.329 & 0.75 & 0.457 \\
PKTLA & -1.052 & 1.60 & 0.121 \\
APB $\mathrm{B}-1$ & 0.153 & 3.30 & 0.003 \\
\hline F-count & 37.31 & & \\
Significance F & 0.000 & & \\
R Square & 0.872 & &
\end{tabular}

Source: Research Data Processed (2017).

From the various tests conducted, it is evident that the factors used as independent variables have significant influences on the variable of harvested area (APB). The magnitude of the effect on the variable of Area of Harvest (APB) by the independent variable is 87.19 percent.

Partial test shows that APBt-1 variable has significant influence to variable of harvest area APB.

Variables Affecting Rice Productivity Indonesia (RB):

Table 2 - Results Two-Stage Least Square against Indonesian Rice Productivity (RB)

\begin{tabular}{llll}
\hline Variable & Coefficient & t-value & Significance \\
\hline Constanta & 14498.06 & 4.33 & 0.000 \\
PB & 1.095 & 0.67 & 0.510 \\
PPUK & 0.064 & 1.87 & 0.074 \\
T & 55.986 & 2.36 & 0.027 \\
W & 119.930 & 2.76 & 0.011 \\
APB & 0.002 & 4.15 & 0.000 \\
PPES & 0.0001 & 0.02 & 0.983 \\
RB & 0.193 & 6.22 & 0.000 \\
\hline F-count & 94.62 & & \\
Significance F & 0.000 & & \\
R Square & 0.953 & &
\end{tabular}

Source: Research Data Processed (2017).

Partial test can be seen that the variable of interest rate (T), wage variable (W), variable of harvest area (APB), and RBt-1 variable have significant influence to productivity variable $(\mathrm{RB})$.

Influential Variables against Price of Rice (PB):

Table 3 - Results Two-Stage Least Square on Price of Rice (PB)

\begin{tabular}{lcll}
\hline Variable & Coefficient & t-value & Significance \\
\hline Constanta & 59.060 & 1.68 & 0.103 \\
$\mathrm{PW}$ & $-1.46 \times 10^{-8}$ & 6.29 & 0.000 \\
$\mathrm{~PB}_{\mathrm{t}-1}$ & 0.782 & 6.28 & 0.000 \\
\hline F-count & 19.89 & & \\
Significance F & 0.000 & & \\
R Square & 0.541 & &
\end{tabular}

Source: Research Data Processed (2017).

Simultaneous test can be seen that the factors used as independent variables have a significant influence on the variable Price Rice (PB). 
Partial test can be seen that variable of PW and variable of PBt-1 have significant influence to variable Price Rice (PB) with coefficient respectively equal to $-1,46 \times 10^{-8}$ and 0,782 .

Influential Variables against Imported Rice $(M B)$. Based on the results of the analysis of variables that affect the Import of Rice Indonesia (MB), obtained the regression equation as follows:

\begin{tabular}{llll}
\hline Variable & Coefficient & t-value & Significance \\
\hline Constanta & $-1.805 \times 10^{9}$ & 1.25 & 0.221 \\
PM & -232749 & 0.32 & 0.751 \\
D & 93.548 & 1.04 & 0.310 \\
QB & -0.003 & 0.68 & 0.504 \\
ER & 12246.07 & 0.75 & 0.457 \\
MB $_{\mathrm{t}-1}$ & 0.475 & 2.54 & 0.017 \\
\hline F-count & 3.70 & & \\
Significance F & 0.011 & & \\
R Square & 0.297 & &
\end{tabular}

The simultaneous test can be seen that the variable used as an independent variable has a significant influence on Import Rice (MB) variable with significance value equal to $0,011(<0,050)$. The magnitude of the effect of Rice Import (MB) variable by the independent variable is 29.69 percent.

Partial test can be seen that MBt-1 variable has significant influence on Rice Import variable $(\mathrm{MB})$.

\section{DISCUSSION OF RESULTS}

The performance of rice in Indonesia can be seen from the area of harvest used. The research shows that the farmers rarely consider the price of rice (PB), the price of corn (PJAG), the price of soybean (PKED) and the price of cassava (PKTLA). The high consumption of rice food causes farmers to continue to rely on rice, regardless of the price of corn, soybean prices, and cassava prices. Furthermore, to analyze the biophysical resources of the land, similar to the research conducted by Ziadat, FM, \& Sultan, KA (2011), done In Jordan, states that when selecting land for planting purposes, it is necessary to evaluate the biophysical resources of the land, the analysis of land suitability with plants is a prerequisite for achieving sustainable use of land resources and reducing land degradation, as well as knowing the factors affecting the area of rice harvest. In a study conducted by Kemph (1980), states that the decision to implement food diversification is positively influenced by land use, however, due to the high cost of the practice many farmers are reluctant or to even consider diversifying.

In the rice productivity test, it was found that the variable of interest rate $(T)$, wage variable $(W)$, variable of harvested area (APB), and RBt-1 variable had significant influence on productivity variable (RB)

In the examination of rice import in Indonesia, it was found that imported Rice (MBt-1). This Shows that imports are influenced by previous imports.

Iraj Postchiand Karamat Razmy in (Ploumis-Devick, 1983) states that the use of fertilizer in wheat can improve yield, but applications that exceed a certain amount have a negative effect on productivity.

The interest rate has a positive effect on productivity, indicating that land productivity in Indonesia is indeed influenced by interest rate; this is in line with the research where the significant productivity in Slovakia is the interest rate as the only significant variable.

\section{CONCLUSION}

There is an increasing trend of rice production costs in Indonesia and neighboring countries. In contrary, China displays a trend of reduction in production costs intensively. 
The price of rice (PB), the price of corn (PJAG), the price of soybean (PKED) and the price of cassava (PKTLA), has no effect on the decision on the use of rice fields in Indonesia.

On rice productivity test, it is found that the variable of interest rate $(T)$, wage variable $(\mathrm{W})$, variable of harvested area (APB), and RBt-1 variable have significant influence on productivity variable (RB).

In the aftermath of analysis regarding the rice import in Indonesia, it was found that imported Rice (MBt-1) variable had significant significance value of $0,011(<0,050)$.

\section{REFERENCES}

1. Adesina, A. A., \& Baidu-Forson, J. (1995). Farmers' perceptions and adoption of new agricultural technology: evidence from analysis in Burkina Faso and Guinea, West Africa. Agricultural economics, 13(1), 1-9.

2. Arita, S., Dyck, J., \& Marquardt, D. (2015). Japan, vietnam, and the asian model of agricultural development and trade. Amber Waves, 29-40.

3. Bayu Krisnamurhi, 2006. Penganekaragaman Pangan Sebuah Kebutuhan yang Mendesak. Makalah Seminar Nasional Diversifikasi untuk Mendukung Ketahan Pangan.

4. Calrose rice industry 2014 - market size, growth, and forecasts, acute market reports. (2015, Aug 27). M2 Presswire.

5. Chia, S. (2013). The ASEAN economic community: Progress, challenges, and prospects.

6. Das, S.B. (2013). The ASEAN economic community: A work in progress (Vol. 14).

7. Furuoka, F. (2012). Making of the ASEAN community: economic integration and its impact on workers in Southeast Asia. Researchers World, 3(2), 1-7.

8. Huang, W. Y. (2009). Factors contributing to the recent increase in US fertilizer prices, 2002-08. DIANE Publishing.

9. Heng, M. S., \& H. (2015). Advancing community building for ASEAN. East Asia: An International Quarterly, 32(4), 421-440.

10. Kajisa, K., \& Akiyama, T. (2005). The evolution of rice price policies over four decades: Thailand, Indonesia and the Philippines. Oxford Development Studies, 33(2), 305-329.

11. Kemph, G.S. (1980). An Agroeconomic Land Resource Assessment for Rice Production in The Dominican Republic (Order No. 8112100). Available from ProQuest Dissertations \& Theses Global: The Humanities and Social Sciences Collection.

12. Khush, G. S. (1995). Breaking the yield frontier of rice. GeoJournal, 35(3), 329-332.

13. Kusuma, A., Noy, I., \& Jackson, B. (2017). A viable and cost-effective weather index insurance for rice in Indonesia (No. 6393).

14. Mariano, M.J. (2012). Factors influencing farmers' adoption of modern rice technologies and good management practices in the Philippines. Agricultural Systems, 110, 41-53.

15. Masuda, T. (2009). World soybean production: area harvested, yield, and long-term projections. International Food and Agribusiness Management Review, 12(4), 143-162.

16. Petri, P. A., Plummer, M. G., \& Zhai, F. (2012). ASEAN economic community: A general equilibrium analysis. Asian Economic Journal, 26(2), 93-118.

17. Rachmat, R. (2016). The empirical relationship between price and quality of rice at market level in West Java. Indonesian Journal of Agricultural Science, 7(1), 27-33.

18. Ramiah, K. (1955). Factors Affecting Rice Production (Vol. 80, No. 1, p. 87). LWW.

19. Ray, D.K. (2013). Yield trends are insufficient to double global crop production by 2050. PloS one, 8(6), e66428.

20. Soesastro, H. (2003). An ASEAN Economic Community and ASEAN+ 3: How do they fit together?

21. Soesastro, H. (2007). Implementing the ASEAN economic community (AEC) blueprint.

22. Teguh, D. (2010). Volatility of world rice prices, import tariffs and poverty in Indonesia: a CGE-microsimulation analysis.

23. Timmer, C. P. (1996). Does Bulog stabilize rice prices in Indonesia? Should it try? Bulletin of Indonesian Economic Studies, 32(2), 45-74.

24. Valentina, T.R. et al (2016). ASEAN economy community Indonesian politic of trade in contending with the simple market based production. Researchers World, 7(1), 82-87. 